\title{
BODY CONDITION AND LONGEVITY OF HIGH YIELDING DAIRY COWS
}

\author{
Ž. Novaković, Lj. Sretenović, S. Aleksić, M. M. Petrović, V. Pantelić, D. \\ Ostojić-Andrić, D.Nikšić
}

Institute for Animal Husbandry, 11080, Belgrade-Zemun, Republic of Serbia

Corresponding author: zeljko.novakovic013@gmail.com

Original scientific paper

\begin{abstract}
Body condition of high yielding Holstein-Friesian dairy cows changes during the production cycle. It represents important indicator of achieved level of nutrition and degree of nourishment. BCS is a functional method, and integral part of the strategy and basis of corrective activities in farm management. BCS of cows in all phases of production cycle is important indicator of applied nutrition, but also of the technological process sin general. The amount of body reserves in form of fat tissue cow has before calving as huge impact on incidence of potential post-calving problems, production of milk, reproductive efficiency and health condition. Very often animals are culled from the herds prematurely, which shortenes the life exploitation of cows. Longevity is the ability to survice in certain production conditions. Life expectancy is from the economical aspect the most important functional trait of high yielding cows and represents necessary condition for sustainability of milk production over longer period. Average BCS of culled cows for the first stage of lactation was $3,35(2,41-4,37)$ for the second stage of lactation 3,50 (2,59-4,59), for the third 2,22 (1,44-2,91) and the fourth 2,36 (1,37$3,37)$. Variation coefficient $(\mathrm{Cv})$ ranged from 12,59 to 16,82. Average age of culled cows was 2037,07 days or 5,58 years with variation interval of 742,00 to 5430,00 days. Age at culling showed high variability $(\mathrm{Cv}=45,69)$. Number of culled cows $(n=34$ or $32.69 \%)$ was the highest at the age of over 7 years $(7,10-14,88)$. The same cows showed the highest variability in regard to longevity $(\mathrm{Cv}=17,97)$.
\end{abstract}

Key words: body condition, longevity, production cycle, nutrition

\section{Introduction}

Body condition of high yielding cows is manifested as achieved level of nourishment in certain phases of production cycle. Body condition scoring (BCS) is a precise method to determine the energy reserves in form of subcutaneous fatty tissue deposited in the hip area, in the loin region and tail root. BCS is a procedure with which the nutrition is controlled and well as other necessary conditions in 
function of improvement of production, fertility, health and longevity of high yielding cows. BCS of cows is a functional method, integral part of the strategy and basis of correction measures in farm management. BCS of cows in all phases of production cycle is major indicator of applied nutrition, but also of the whole technological procedure.

The objective is to have cows in optimal body condition at calving, not too thin or too fat. Body condition changes during production process. Early lactation is the most critical period in the production cycle of high-yielding cows. Cows in early lactation are in the negative energy balance (NEB). They loose their body condition through mobilization of body reserves for the purpose of milk synthesis. Level of BCS of all other cows should be within the optimal values in accordance with the phase of the production cycle. Cows in late lactation are in the positive energy balance (PEB). Changes of the body condition should end with the end of lactation. Ideal body condition is the rank which is in the function of the lactation flow and stage (Ferguson et al., 1994; Ruegg and Milton,1995; Dechow et al., 2002; Grubić et al.,2009).

The amount of body reserves at cow's disposal before calving has strong impact on incidence of potential problems immediately after calving, in regard to the amount of produced milk, reproductive efficiency and health condition. The risk of incidence of calving problems is reduced if the cow is in the optimal body condition. Adequate body reserves are precondition for maximum increase of milk yield in the period of early lactation. Excessive body reserves of fat tissue (BCS $>3,75)$ shall intensively be used at the beginning of lactation. Too rapid changes of body condition lead to various metabolic disorders. Cows in poor condition before calving (BCS $\leq 3.00)$ as a rule have reduced production of milk in early lactation, problems with various metabolic disorders and delayed onset of reproduction cycle. Very often it leads to premature culling of animals from the herd, which shortenes the production life. The consequence is significant reduction in the genetic progress and economical efficiency of production (Edmonson et al.,1989; Waltner et al., 1993; Pedron et al., 1993; Hady et al.,1994; Ruegg and Milton, 1995;).

Longevity is the ability to survive in certain production conditions. Life expectancy in the economical sense is the most important functional trait of highyie;ding cows and represents necessary condition of sustainability of production over longer period of time. Longevity depends primarily on the healht condition of animals. The extension of production life of animals reduces the remount rate of the herd, which enables increase of the selection intensity and better economical results (Vukašinovic et al., 1997; Boettcher et al., 1999; deVries, 2003; Caraviello et al., 2004).

Heritability for longevity is low and ranges betwee 0,03 and 0,20 depending on the method selected to evaluate the longevity (Boettcher et al., 1999). Based on numerous milk recording data, in many countries, due to the significance of life 
duration and positive economical results, dairy animals are selected for longevity (Jairath et al., 1998).

Intensive exploitation of cows during longer time period leads to incidence of considerable number of longevity related problems. Supply of adequate quantities of energy to the organism is main problem in nutrition of high-yielding cows. Reasons for culling of cows are often consequences of mistakes made in the nutrition technology expressed through inadequate body condition of cows leading to incidence of numerous problems (fertility disorders, deaths, emergency slaughtering, leg problems, diseases of reproductive organs, etc.). shortening of the exploitation period of cows in the production process because of high rate of culling increases ther herd remount, reduces the genetic progress and general economic results (Vollema and Groen, 1996, Lotthamer, 1999, Hare et al., 2006).

Objective of this srudy was to investigate by applying adequate methodology, main indicators of BCS and longevity of high-yielding cows in production cycle. Obtained results will be in function of more objective consideration of technological condition present on farms and of cows' potentials for longer life expectancy.

\section{Material and methods}

The case study was BCS and longevity of high-yielding cows in production cycle. Sample comprised 107 cows of Holstein-Friesian breed. Animals included in the study sample were in conditions of tie housing, nutrition consisted of complete mixed diets with addition of concentrate mixtures according to realized milk performance. All animals were under same cconditions in regard to the care, health condition and exploitation method. Average milk yield in standard lactation was 7500 kilograms per cow.

According to the plan of investigation the body condition was scored according to standards defined for each phase of production cycle (Edmonson et al., 1989). BCS of each cow was done:

1. at the beginning of dry period,

2. two days after calving,

3 . in the peak of lactation (40th day) and

4. in mid lactation (150th day).

BCS system for high-yielding cows is created in the form of map (chart) precisely prepared and which includes all body regions and areas/fields considered important for allocation of general score. Within the scoring system three large body regions are defined: loin, pelvic and tail root. Each region of the cow's body 
has certain number of body areas/fields. Loin has 4, pelvic region 3 and root of the tail 1.

Animals were scored individually. Each body area/field within regions was scored separately. Score of each body area/field is indicator of body condition on the level of body regions of each cow. Total BCS is score for all body regions. BCS ranges from minimum 1 to maximum 5. For measuring of changes in level of BCS a scale is used with continuous increase by 0,25 of the score. Each phase of production cycle has its optimal score.

In the analysis of longevity of cows data was used from farm records. For each cow the life duration was calculated representing the period from date of birth to date of culling from the herd.

Analysis of data base used for BCS and longevity assessment was done by applying adequate mathematical-statistical methods. Information on study results is presented in tables using basic indicators of descriptive statistics (arithmetic mean, variation interval, standard deviation, variation coefficient). Experimental results were statistically analyzed by applying the package STATISTICA v. 6. StatSoft, Inc. (2003).

\section{Results and Discussion}

Established results in the study of BCS of culled cows in production cycle are presented in following tables and graphs.

Table 1. Average BCS of culled cows in different phases of production cycle

\begin{tabular}{|c|c|c|c|c|}
\hline \multirow{2}{*}{ Indicators } & \multicolumn{4}{|c|}{ Average score } \\
\cline { 2 - 5 } & \multicolumn{4}{|c|}{ Phase of production cycle } \\
\cline { 2 - 5 } & 1 & 2 & 3 & 4 \\
\hline $\bar{X}$ & 3,35 & 3,50 & 2,22 & 2,36 \\
\hline $\mathrm{n}$ & 107 & 104 & 84 & 66 \\
\hline $\operatorname{Max}$ & 4,37 & 4,59 & 2,91 & 3,37 \\
\hline $\mathrm{Min}$ & 2,41 & 2,59 & 1,44 & 1,37 \\
\hline $\mathrm{Sd}$ & 0,52 & 0,53 & 0,28 & 0,40 \\
\hline $\mathrm{Cv}$ & 15,48 & 15,10 & 12,59 & 16,82 \\
\hline
\end{tabular}

Average BCS of culled cows for first stage of lactation was 3,35 (2,41$4,37)$, second phase of the production cycle 3,50 (2,59-4,59), and for third and fourth phases of production cycle 2,22 (1,44-2,91) and 2,36 (1,37-3,37), respectively. Variation coefficient (Cv) ranged from 12,59 to 16,82 (Table 1.; Graphs 1-4). 
Ruegg and Milton (1995) state average value of BCS at calving of 3,23 $(2,00 ; 4,50)$. Average BCS at calving was 3,18 in the first lactation and 3,07 in the second lactation, in the post-calving period it was 2,91 in the first and 2,82 in the second lactation, and prior to dry period it was 3,12 in the first and 3,19 in the second lactation, during dry period it was 3,31 in the first and 3,45 in the second lactation (Dechow et al., 2002). Hady et al.(1994) in their studies state average BCS which at the beginning of dry period was $2,89(2,50 ; 3,50)$, in later dry period $-3,00(2,50 ; 3,75)$, in period of lactation from 31-60 days $2,27(1,00 ; 3,25)$ and in period of lactation from 151-180 days $2,50(2,25 ; 3,25)$.

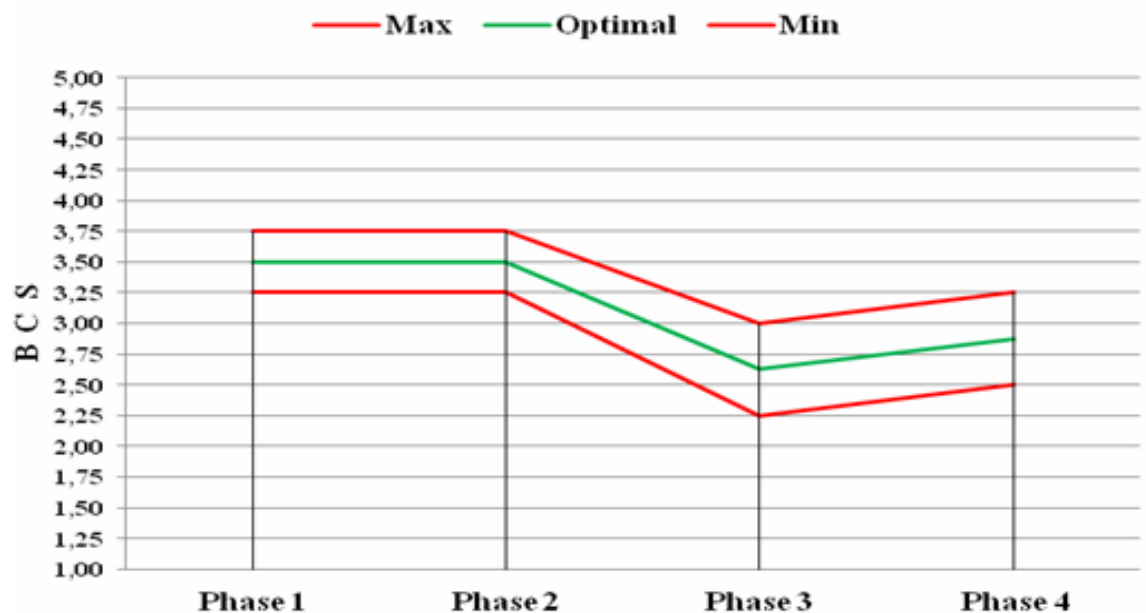

Graph 1. Recommended BCS of cows in different production cycle phases

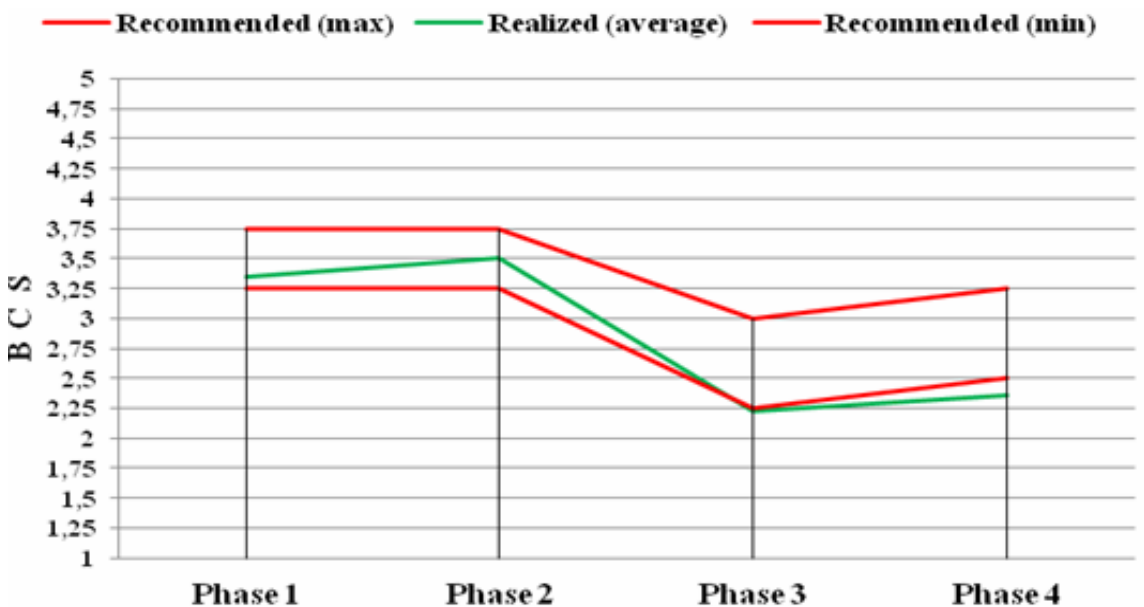

Graph 2. Realized BCS in different phases of production cycle 


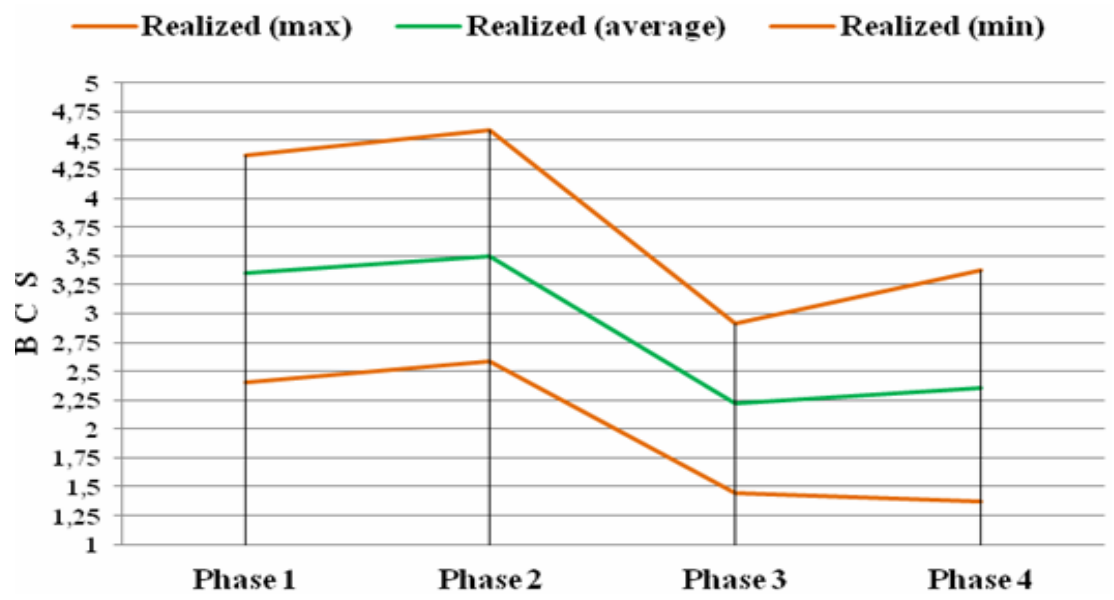

Graph 3. Realized BCS in different phases of production cycle

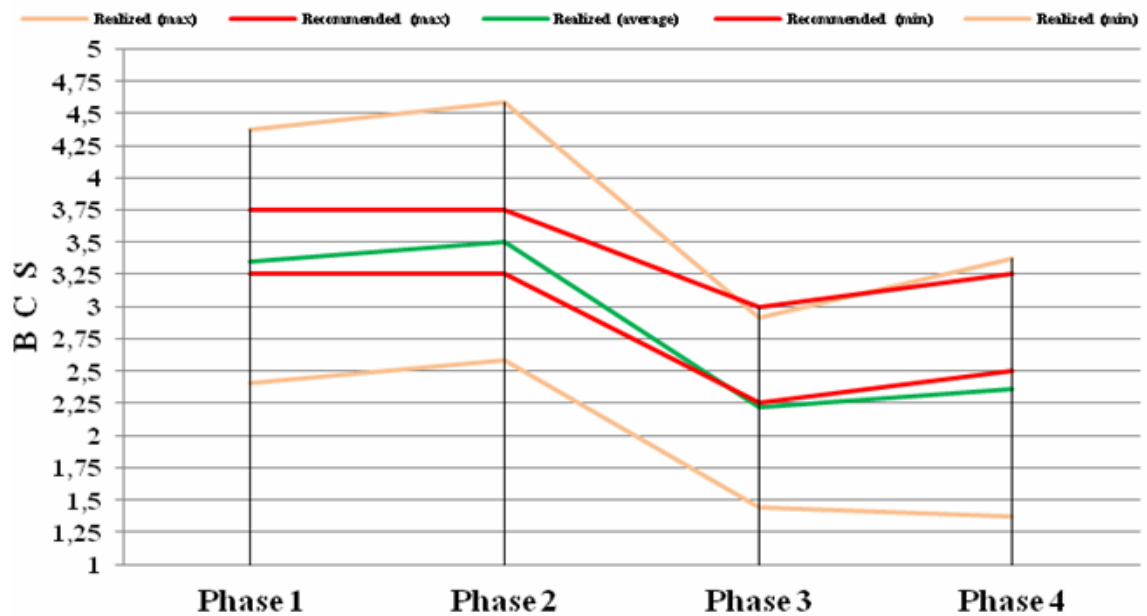

Graph 4. Realized BCS in different phases of production cycle

Analysis of indicators of BCS distribution in culled cows is presented in the following tables: 
Table 2. Distribution of BCS of cows in different phases of production cycle

\begin{tabular}{|c|c|c|c|c|}
\hline \multirow{3}{*}{$\mathrm{BCS}$} & \multicolumn{4}{|c|}{ Number of animals } \\
\hline & \multicolumn{4}{|c|}{ Production cycle phase } \\
\hline & 1 & 2 & 3 & 4 \\
\hline $1,00-1,25$ & 0 & 0 & 0 & 0 \\
\hline $1,26-1,50$ & 0 & 0 & 1 & 1 \\
\hline $1,51-1,75$ & 0 & 0 & 2 & 3 \\
\hline $1,76-2,00$ & 0 & 0 & 16 & 8 \\
\hline $2,00-2,25$ & 0 & 0 & 25 & 14 \\
\hline $2,26-2,50$ & 1 & 0 & 24 & 17 \\
\hline $2,51-2,75$ & 11 & 5 & 15 & 13 \\
\hline $2,76-3,00$ & 23 & 19 & 1 & 7 \\
\hline $3,01-3,25$ & 17 & 15 & 0 & 1 \\
\hline $3,26-3,50$ & 15 & 18 & 0 & 2 \\
\hline $3,51-3,75$ & 12 & 16 & 0 & 0 \\
\hline $3,76-4,00$ & 12 & 9 & 0 & 0 \\
\hline $4,01-4,25$ & 13 & 12 & 0 & 0 \\
\hline $4,26-4,50$ & 3 & 9 & 0 & 0 \\
\hline $4,51-4,75$ & 0 & 1 & 0 & 0 \\
\hline $4,76-5.00$ & 0 & 0 & 0 & 0 \\
\hline $\mathrm{n}$ & 107 & 104 & 84 & 66 \\
\hline
\end{tabular}

Realized values point out that in the distribution of average BCS of cows in the first phase of production cycle, of total 107 cows, the majority of animals ( $\mathrm{n}=23$ or $21,50 \%$ ) had BCS in range from 2,76 to 3,00 (Table 2). Below this BCS range there were 12 animals or $11,21 \%$, and above this BCS 72 animals or $67,29 \%$, within all ranges.

In the second phase of production cycle, of total 104 scored cows, the majority of animals ( $\mathrm{n}=19$ or $18,27 \%$ ) ranged in the interval of BCS from 2,76 to 3,00 . Below this BCS range there were 5 animals or $4,81 \%$, and above this range 80 animals or $76,92 \%$, within all ranges. It is important to point out that in this production phase, 31 cows were in the BCS range from 3,76 to 4,75 or $29,81 \%$. During dry period, within BCs distribution a shift occured towards higher values, which is consequence of increase of body condition in this phase of production cycle.

In the third phase, of 84 scored animals, the majority of animals ( $\mathrm{n}=25$ or $29,76 \%$ ) were in the BCS range of 2,00 to 2,25. Below this BCS level were 19 cows or $22,62 \%$, and above this range 40 cows or $47,62 \%$, within all ranges. In the 
period of early lactation, within the structure of BCS range a shift occured towards lower values, as a result of decrease in body condition of cows.

In the fourth phase of production cycle, of total of 66 scored animals, the majority of animals ( $\mathrm{n}=17$ or $25,76 \%$ ) were in $\mathrm{BCS}$ range from 2,26 to 2,50 . Below this BCS range were 26 animals or $39,39 \%$, and 23 cows or $34,85 \%$ above this range. In the mid-lactation, within the BCS structure, no shift towards higher values occurred. In general, results deviated significantly from recommended values for BCS.

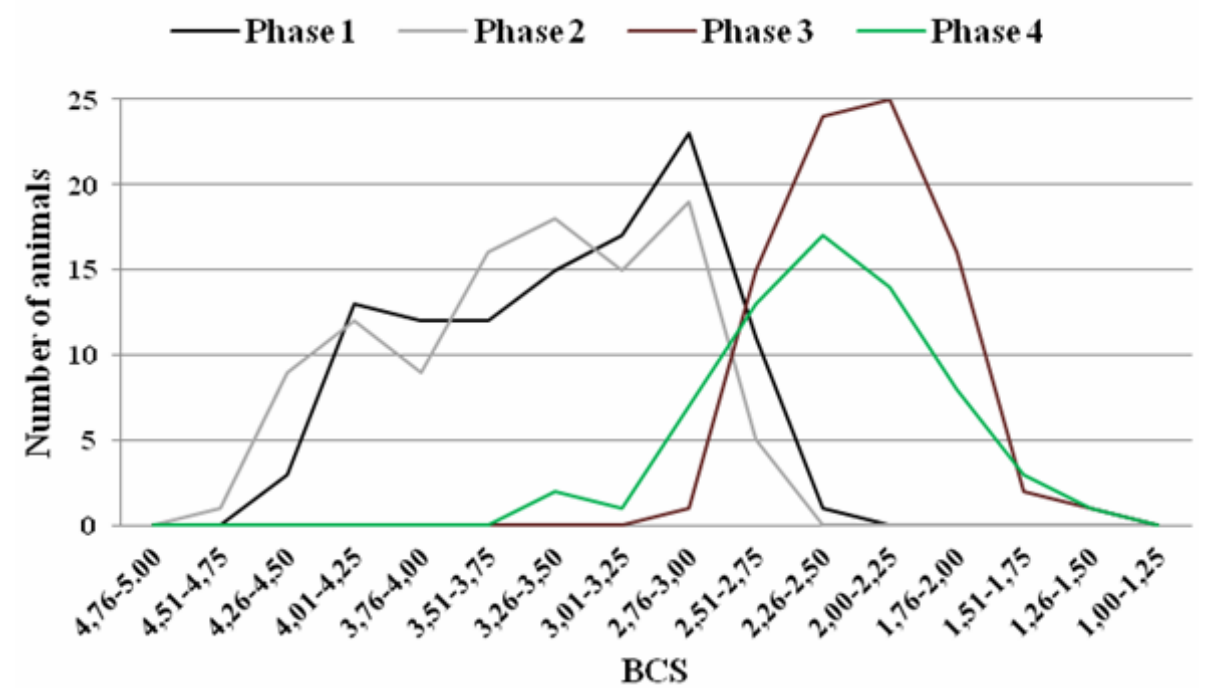

Graph 5. Distribution of culled cows according to BCS ranges

Important characteristic of longevity traits was high variability. Longevity is described as ability to survive in certain production circumstances and represents the most important functional trait of high-yielding dairy cows. The average age of animals at culling is presented in following tables.

Table 3. Average age of culled animals

\begin{tabular}{|c|c|c|}
\hline Indicators & Age at culling (days) & Age at culling (years) \\
\hline$\overline{\mathrm{X}}$ & 2037,07 & 5,58 \\
\hline $\mathrm{n}$ & 107 & 107 \\
\hline $\mathrm{Max}$ & 5430,00 & 14,88 \\
\hline $\mathrm{Min}$ & 742,00 & 2,04 \\
\hline $\mathrm{Sd}$ & 930,77 & 2,55 \\
\hline $\mathrm{Cv}$ & 45,69 & 45,69 \\
\hline
\end{tabular}


The average age of culled cows was 2037,07 days or 5,58 years with variation interval from 742,00 to 5430,00 days, i.e., from 2,04 to 14,88 years. Age at culling showed high variability $(\mathrm{Cv}=45,69)$ (Table 3.).

Established statistical indicators correspond to results indicating relatively short life time of high-yielding dairy animals, obtained in the study of Vukasinovic et al., 1997; de Vries, 2003, Hare et al., 2006.

Table 4. Distribution of culled cows according to age intervals

\begin{tabular}{|c|c|c|c|c|c|c|}
\hline \multirow{2}{*}{ Indicators } & \multicolumn{7}{|c|}{ Age at culling (year) } \\
\cline { 2 - 7 } & $\leq 3$ & $3,1-4$ & $4,1-5$ & $5,1-6$ & $6,1-7$ & $>7$ \\
\hline $\bar{X}$ & 2,63 & 3,58 & 4,40 & 5,55 & 6,45 & 8,68 \\
\hline $\mathrm{n}$ & 18 & 19 & 14 & 9 & 10 & 34 \\
\hline Max & 2,95 & 3,99 & 4,92 & 5,92 & 6,83 & 14,88 \\
\hline Min & 2,04 & 3,06 & 4,01 & 5,20 & 6,03 & 7,10 \\
\hline Sd & 0,27 & 0,33 & 0,31 & 0,22 & 0,31 & 1,56 \\
\hline $\mathrm{Cv}$ & 10,38 & 9,28 & 7,02 & 4,02 & 4,75 & 17,97 \\
\hline
\end{tabular}

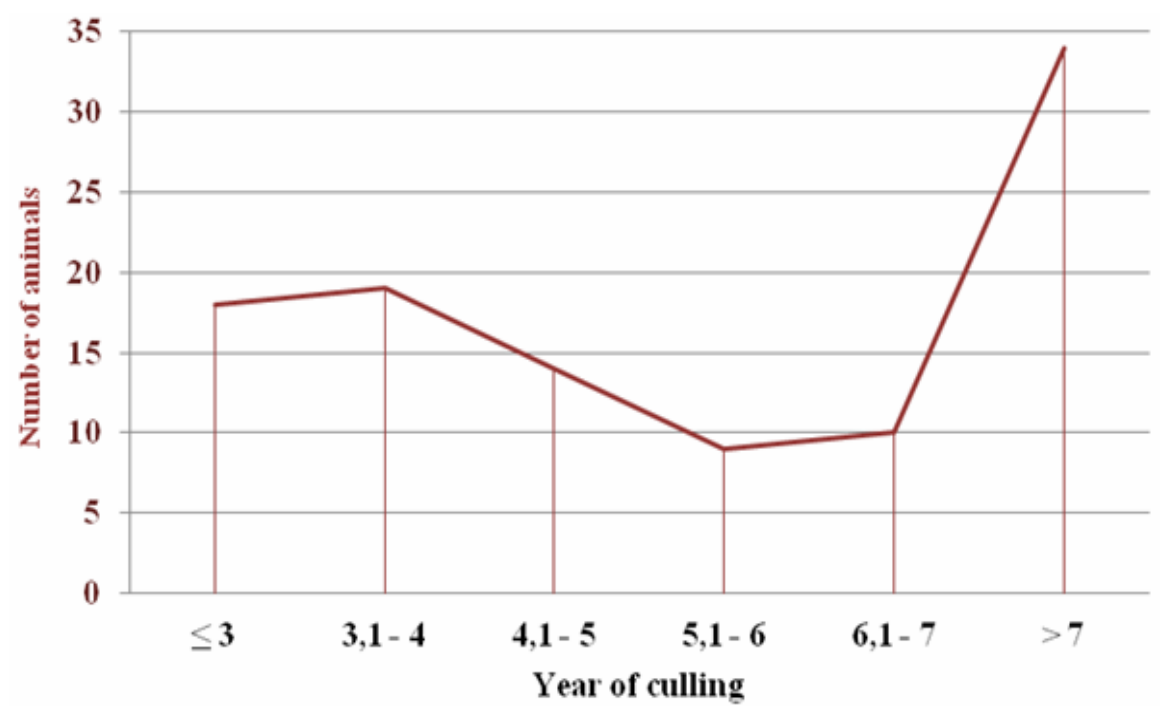

Graph 6. Average age of culled cows according to age intervals Number of

Number of culled cows $(n=34$ or $32.69 \%)$ over the age of 7 years $(7,10$ $14,88)$ was the highest. Same cows showed the highest variability in regard to longevity $(\mathrm{Cv}=17,97)$ (Table 4.; Graph 6.). 
Table 5. Average of cows in the production cycle according to age intervals at culling

\begin{tabular}{|c|c|c|c|c|c|}
\hline \multirow{2}{*}{$\begin{array}{c}\text { Age of cows at culling } \\
\text { (year) }\end{array}$} & \multirow{2}{*}{$\bar{X}$} & \multicolumn{4}{|c|}{ Average scores } \\
\cline { 3 - 6 } & & \multicolumn{4}{|c|}{ Phases of production cycle } \\
\cline { 3 - 6 } & & 1 & 2 & 3 & 4 \\
\hline$\leq 3$ & 2,63 & 3,30 & 3,48 & 2,26 & 2,30 \\
\hline $3,1-4$ & 3,58 & 3,39 & 3,53 & 2,24 & 2,37 \\
\hline $4,1-5$ & 4,54 & 3,49 & 3,66 & 2,20 & 2,23 \\
\hline $5,1-6$ & 5,55 & 3,08 & 3,25 & 2,04 & 2,55 \\
\hline $6,1-7$ & 6,77 & 3,23 & 3,40 & 2,25 & 2,54 \\
\hline$>7$ & 9,26 & 3,31 & 3,42 & 2,20 & 2,38 \\
\hline
\end{tabular}

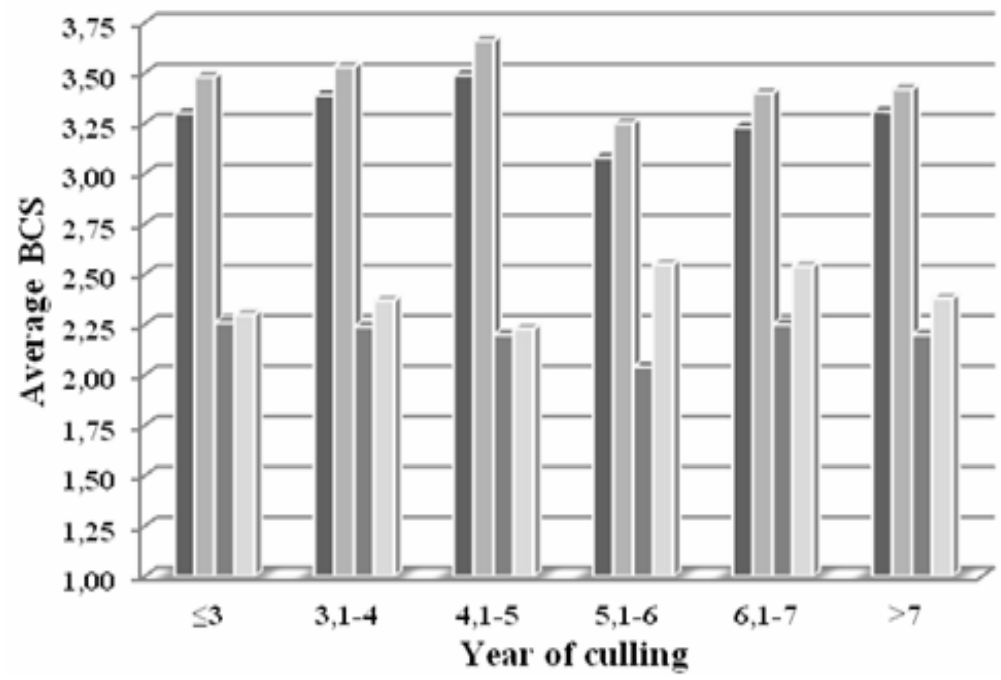

- Phase 1

= Phase 2

- Phase 3

Phase 4

Graph 7. Average BCS of cows according to intervals of age at culling

The highest average BCS level in the fist and second phase of production cycle was recorded in cows 4,1 to 5 years old at culling $(3,49 ; 3,66)$, in the third phase, cows less than 3 years old at $(2,26)$ and in the fourth phase, cows from 5,1 to 6 years old at culling $(2,55)$. The lowest average BCS level in the first, second and third phase of production cycle was recorded in cows from 5.1 to 6 years old at culling $(3,08 ; 3,25 ; 2,04)$, in the fourth phase, cows from 4.1 to 5 years of age at culling $(2,23)$ (Table 5.; Graph 7.). 


\title{
Conclusion
}

Results of the analysis of realized body condition scores of culled cows showed that scores often were outside the recommended optimal values for each phase of production cycle. Structure of culled cows clearly indicates that application of the body conditions scoring method offers objective, realistic opportunity to manage more efficiently changes in body reserves of high-yielding dairy animals. Body condition of animals in all phases of production cycle is important indicator of applied nutrition, but also of technological process sin general. Results of research indicate relatively short life time (longevity) of highyielding dairy cows of Holstein-Friesian breed. Expression of this trait in studied sample is not at satisfactory level, which directly contributes to decrease in life time milk production with direct consequences on economical efficiency of production. Intensive way of cow exploitation in conditions which do not provide optimal level of nutrition over longer period of time leads to incidence of numerous problems realted to their longevity. The most important problem in nutrition of high-yielding cows is how to ensure adequate quantity of energy. Many cullings are related to inadequate body condition as basis for many different health problems which directly influence the longevity of high-yielding dairy animals.

\section{Acknowledgment}

This work was financed by the Ministry of Education and Science, Republic of Serbia, project TR 31053.

\section{Telesna kondicija i dugovečnost visokomlečnih krava}

\author{
Ž. Novaković, Lj. Sretenović, S. Aleksić, M. M. Petrović, V. Pantelić, D. Ostojić- \\ Andrić, D.Nikšić
}

\section{Rezime}

Prikazani rezultati jasno ukazuju na relizovane prosečne vrednosti, interval varijacije, standardnu devijaciju, koeficijent varijacije ispitivanih krava holštajnfrizijske rase. Prosečna BCS izlučenih krava za prvu fazu laktacije iznosila je $3,35(2,41-4,37)$ za drugu fazu 3,50 (2,59-4,59), za treću fazu 2,22 $(1,44-2,91)$ i četvrtu fazu 2,36 (1,37-3,37). Koeficijent varijacije (Cv) kretao se od 12,59 do 16,82. Realizovane vrednosti ukazuju da je kod distribucije prosečnih BCS krava u prvoj fazi proizvodnog ciklusa od ukupnog broja krava koji čini 107 grla najviše ( $\mathrm{n}=23$ ili 21,50 \%) bilo u intervalu BCS od 2,76 do 3,00. Ispod tog intervala BCS 
bilo je 12 grla ili $11,21 \%$, a iznad 72 grla ili $67,29 \%$. U drugoj fazi od ukupno 104 ocenjenih krava najviše grla ( $\mathrm{n}=19$ ili $18,27 \%$ ) bilo je u intervalu BCS od 2,76 do 3,00 . Ispod tog intervala BCS bilo je 5 grla ili $4,81 \%$, a iznad 80 grlo ili $76,92 \%$. U ovoj fazi poizvodnje u intervalu BCS od 3,76 do 4,75 bilo 31 krave ili $29,81 \%$. U trećoj fazi od 84 ocenjene krave najviše grla ( $\mathrm{n}=25$ ili $29,76 \%$ ) bilo je u intervalu BCS od 2,00 do 2,25. Ispod navedenog nivoa BCS bilo je 19 grla ili $22,62 \%$, a iznad 40 krava ili 47,62\%. U četvrtoj fazi od ukupno 66 ocenjena grla najviše krava $(\mathrm{n}=17$ ili $25,76 \%$ ) bilo je $\mathrm{u}$ intervalu BCS od 2,26 do 2,50. Ispod tog intervala BCS bilo je 26 grla ili 39,39\%, a iznad 23 krave ili 34,85\%. U celini posmatrano rezultati su značajno su odstupali od preporučenih vrednosti za BCS. Prosečna starost krava kod izlučenja iznosila je 2037,07 dana ili 5,58 godina sa intervalom varijacije od 742,00 do 5430,00 dana, odnosno, od 2,04 do 14,88 godina. Starost kod izlučenja pokazala je visoku varijabilnost $(\mathrm{Cv}=45,69)$. Broj izlučenih krava $(\mathrm{n}=34$ ili $32.69 \%)$ bio je najveći u starosti preko 7 godina $(7,10-14,88)$. Iste krave pokazale su i najveću varijabilnost u pogledu dugovečnosti $(\mathrm{Cv}=17,97)$. Najviši prosečan nivo BCS u prvoj i drugoj fazi proizvodnog ciklusa imale su krave koje su bile stare na izlučenju od 4,1 do 5 godina $(3,49 ; 3,66)$, u trećoj fazi krave koje su bile stare na izlučenju od manje od 3 godine $(2,26)$ i u četvrtoj fazi krave koje su bile stare 5,1 do 6 godina $(2,55)$. Najniži prosečan nivo BCS u prvoj, drugoj i trećoj fazi imale su krave koje su bile stare na izlučenju od 5.1 do 6 godina $(3,08$; $3,25 ; 2,04)$, u četvrtoj fazi krave koje su bile stare na izlučenju 4.1 do 5 godina $(2,23)$.

\section{Literatura:}

BOETTCHER, P. J., JAIRATH, L. K., DEKKERS, J.C.M. (1999): Comparison of methods for genetic evaluation of sires for survival of their daughters in the first three lactations. J. Dairy Sci., 825, 1034-1044.

CARAVIELlO, D. Z., WEIGEL, K. A., GIANOLA, D. (2004): Prediction of longevity breeding values for us holstein sires using survival analysis methodology. J. Dairy Sci., 8710, 3518-3525.

DECHOW C.D. , ROGERS G.W., CLAY J.S. (2002): Heritability and Correlations Among Body Condition Score Loss, Body Condition Score, Production and Reproductive Performance, J. Dairy Sci. 85:3062-3070

DE VRIES A. (2003): Productive life of dairy cows in Florida. Department of Animal Sciences University of Florida, Gainesville.

EDMONSON A.J., LEAN I.J., WEAWER L. D., FARVER T., WEBSTER G. (1989): A body condition scoring chart of Holstein dairy cows. J. Dairy Sci. 72:68. FERGUSON J.D., GALLIGAN D.T., THOMSEN N. (1994): Principal Descriptors of Body Condition Score in Holstein Cows, J Dairy Sci 77:2695-2703. 
GRUBIĆ G., NOVAKOVIĆ Ž., ALEKSIĆ S., SRETENOVIĆ Lj., PANTELIĆ V., OSTOJIĆ-ANDRIĆ D. (2009): Evaluation of the body condition of high yielding cows, Biotechnology in Animal Husbandry 25 (1-2), p 81-91.

HARE, E., NORMAN, H. D., WRIGHT, J. R. (2006): Survival rates and productive herd life of dairy cattle in the United States. J. Dairy Sci., 899, 37133720 .

HADY P.J., DOMECQ J.J., KANEENE J.B.(1994):Frequency and in Dairy Cattle Precision of Body Condition Scoring, J Dairy Sci 77:1543-1547

JAIRATH, L., DEKKERS, J.C.M., SCHAEFFER, L. R., LIU, Z., BURNSIDE, E. B., KOLSTAD, B. (1998): Genetic evaluation for herd life in Canada. J. Dairy Sci., 812, 550-562.

LOTTHAMMER, K.H. (1999): Beziehungen zwischen Leistungsniveau, Gesundheit, Fruchtbarkeit und Nutzungsdauer bei Milchrindern. Tierärztliche Umschau, 54: 544-553.

PEDRON O., CHELI F., SENATORE E., BAROLI D., RIZZI R. (1993): Effect of body condition score at calving on performance, some blood parameters, and milk fatty acid composition in dairy cows. J. Dairy Sci. 76:2528-2535.

RUEGG P.L., MILTON R.L. (1995): Body condition scores of Holstein cows on Prince Edward Island, Canada: Relationship with yield, reproductive performance and disease. J Dairy Sci; 78:552-64.

VOLLEMA, A. R., GROEN, A. F. (1996): Genetic parameters of longevity traits of an upgrading population of dairy cattle. J. Dairy Sci., 7912, 2261-2267.

VUKASINOVIC, N., MOLL, J., KUNZI, N. (1997): Analysis of productive life in Swiss Brown cattle. J. Dairy Sci., 8010, 2572-2579.

WALTNER S.S., McNAMARA J.P., HILLERS J.K. (1993): Relationships of Body Condition Score to Production Variables in High Producing Holstein Dairy Cattle, J Dairy Sci 76: 3410-3419. 